\title{
THE NEUROPEPTIDE PROCTOLIN INDUCES PHOSPHORYLATION OF A 30 kDa PROTEIN ASSOCIATED WITH THE THIN FILAMENT IN CRUSTACEAN MUSCLE
}

\author{
BERIT BRÜSTLE ${ }^{1}$, SABINE KREISSL ${ }^{1}$,*, DONALD L. MYKLES ${ }^{2}$ AND WERNER RATHMAYER ${ }^{1}$ \\ ${ }^{1}$ Department of Biology, University of Konstanz, D-78457 Konstanz, Germany, and ${ }^{2}$ Department of Biology, \\ Colorado State University, Fort Collins, CO 80523, USA \\ *Author for correspondence (e-mail: s.kreissl@uni-konstanz.de)
}

Accepted 14 May 2001

\begin{abstract}
Summary
In the isopod Idotea emarginata, the neuropeptide proctolin is contained in a single pair of motoneurones located in pereion ganglion 4. The two neurones supply dorsal extensor muscle fibres of all segments. Proctolin $\left(1 \mu \mathrm{moll}^{-1}\right)$ potentiates the amplitude of contractures of single extensor muscle fibres elicited by $10 \mathrm{mmoll}^{-1}$

phosphorylation of this protein was significantly increased by treating the fibres with proctolin. After separation of myofibrillar filaments, a $30 \mathrm{kDa}$ protein was found only in the thin filament fraction. This protein is phosphorylated and detected by an antiserum against crustacean troponin $I$.
\end{abstract} caffeine. In western blots of myofibrillar proteins isolated from single muscle fibres and treated with an antiphosphoserine antibody, a protein with an apparent molecular mass of $30 \mathrm{kDa}$ was consistently found. The
Key words: Idotea emarginata, nervous system, motoneurone, modulation, actin, myosin, troponin I, contraction, caffeine.

\section{Introduction}

The penta-peptide proctolin (amino acid sequence RYLPT) was initially isolated from the hindgut of the cockroach Periplaneta americana (Brown and Starrat, 1975) and was subsequently localised in nervous systems of a number of arthropods. In insects and crustaceans, it is contained within identified neurones as a cotransmitter being released in the central nervous system, at neuromuscular synapses and from neurohaemal organs (O'Shea, 1985; Siwicki et al., 1987; Orchard et al., 1989). Proctolin causes graded contractures of some visceral and skeletal muscles in insects and crustaceans (Schwarz et al., 1980; Orchard et al., 1989; Baines and Downer, 1992). It also potentiates contractions of skeletal or visceral muscles either when produced myogenically (Evans and Myers, 1986; Lange et al., 1986), or upon activity of motoneurones or upon depolarisation by high $\mathrm{K}^{+}$or current (Orchard et al., 1989; Baines and Downer, 1992; Belanger and Orchard, 1993; Erxleben et al., 1995; Facciponte et al., 1996; Jorge-Rivera et al., 1998).

The mechanisms underlying the potentiations involve both pre- and postsynaptic actions. Presynaptically, proctolin can increase transmitter output at some neuromuscular endings (Belanger and Orchard, 1993; Pasztor and Golas, 1993; Rathmayer et al., 2001). Postsynaptically, proctolin closes nonvoltage-dependent $\mathrm{K}^{+}$channels (Erxleben et al., 1995; Baines et al., 1996; Walther et al., 1998) resulting in an increase of input resistance and time constant of the muscle membrane and thus in stronger summation of excitatory junctional potentials. It also stimulates an influx of $\mathrm{Ca}^{2+}$ into muscle fibres (Baines and
Downer, 1992; Wilcox and Lange, 1995) by increasing the open probability of voltage-sensitive sarcolemmal $\mathrm{Ca}^{2+}$ channels (Bishop et al., 1991a; Erxleben and deSantis, 1998). The preand postsynaptic effects of proctolin add synergistically to potentiate contractions of muscle fibres (for summary of the combined effects in muscle fibres of the isopod Idotea emarginata and Idotea baltica, see Rathmayer et al., 2001).

There is some indication that the effects of proctolin on sarcolemmal ion channels may be mediated by protein phosphorylation via a cAMP signalling pathway: activators or inhibitors of this pathway mimic or inhibit the effects of proctolin, respectively (Evans, 1984; Bishop et al., 1991a; Erxleben et al., 1995; Erxleben and deSantis, 1998). In some muscles, however, proctolin increases inositol trisphosphate (Ins $P_{3}$ ) and may activate protein kinase $\mathrm{C}$ because $\operatorname{Ins} P_{3}$ and phorbol esters mimic the potentiating effect of proctolin on contractions (Baines and Downer, 1992; Lange and Nykamp, 1996; Wegener and Nässel, 2000). The action of proctolin on sarcolemmal ion channels with different ion selectivity, the variety of possible signalling pathways and the finding that multiple proctolin receptor subtypes exist in insect visceral muscles (Baines et al., 1996; Mazzocco-Manneval et al., 1998) suggest that additional intracellular targets could be involved in mediating the proctolin-induced potentiation of contractions. Since it is now widely accepted that muscle contractions are modulated by reversible phosphorylation of target proteins in the sarcolemma, sarcoplasmic reticulum (SR) and myofilaments, for example, myosin light chains (Bárány 
and Bárány, 1980; Horowitz et al., 1996, for review), we studied the effect of proctolin on phosphorylation of myofibrillar proteins in a crustacean.

The marine isopod I. emarginata has the advantage that several neuropeptides can be localised in identified motoneurones (Kreissl et al., 1999; Rathmayer et al., 2001) and the effect of modulators on isolated membrane currents under voltage-clamp conditions and the effects on contractions can be analysed in single identified muscle fibres (Erxleben et al., 1995; Kreissl et al., 1999; Rathmayer et al., 2001). In the present study we show that proctolin also potentiates muscle contractures elicited by caffeine, which is known to induce $\mathrm{Ca}^{2+}$ release from internal stores via activation of the ryanodine-sensitive $\mathrm{Ca}^{2+}$ channel of the SR of crustacean muscles (Lea, 1996; Zhang et al., 1999). By studying phosphorylation of myofibrillar proteins we show that proctolin induces phosphorylation of an intramuscular $30 \mathrm{kDa}$ protein. After separation of myofilaments, a $30 \mathrm{kDa}$ protein was found only in the thin filament fraction. This protein is phosphorylated and detected by an antiserum against lobster troponin $\mathrm{I}_{3}$. We also show that proctolin immunoreactivity is associated with extensor muscle fibres of I. emarginata and identify two single motoneurones as the centre of origin of this peptidergic innervation.

\section{Materials and methods \\ Animals and saline}

All experiments were performed on adult males of Idotea emarginata Fabricius 1798 raised in the animal facility of the University of Konstanz.

For all experiments, the saline had a composition of (in mmoll $1^{-1}$ ): $490 \mathrm{NaCl}, 8 \mathrm{KCl}, 10 \mathrm{CaCl}_{2}, 12 \mathrm{MgCl}_{2}, 10$ Hepes. Proctolin (Sigma, Deisenhofen, Germany) was dissolved in distilled water at a concentration of $1 \mathrm{mmoll}^{-1}$. Samples of the stock solution were stored at $-20{ }^{\circ} \mathrm{C}$ and diluted in saline prior to experiments.

\section{Preparation and protocols for immunocytochemistry}

Anatomy and preparation of the dorsal extensor muscles have been described previously (Kreissl et al., 1999). Specimens were fixed in $4 \%$ paraformaldehyde, $0.5 \%$ glutaraldehyde in $100 \mathrm{mmoll}^{-1}$ Tris $(\mathrm{pH} \mathrm{7.4)}$ for $3 \mathrm{~h}$ at room temperature (approximately $22^{\circ} \mathrm{C}$ ) and washed in salinesubstituted Tris buffer (SST: $160 \mathrm{mmol}^{-1} \mathrm{NaCl}, 50 \mathrm{mmoll}^{-1}$ Tris, pH 7.6) with $0.1 \%$ Triton X-100 (TRX; washing buffer) with a last wash continued overnight. The preparation was enzymatically permeabilised for $20 \mathrm{~min}$ with $0.5 \mathrm{mg}$ collagenase, $0.5 \mathrm{mg}$ hyaluronidase in $1 \mathrm{ml} 10 \mathrm{mmol}^{-1}$ Tris ( $\mathrm{pH}$ 7.4), and extensively rinsed in washing buffer for $6 \mathrm{~h}$. Nonspecific binding of the primary antiserum was blocked by preincubation in blocking solution (SST, $0.1 \%$ TRX, 0.5\% BSA) for $1 \mathrm{~h}$ and microbial contamination of the specimens was prevented by adding $0.02 \%$ sodium azide (Fluka, Buchs, Switzerland) to incubation and washing solutions. Incubation of the specimens in the polyclonal anti-proctolin serum, diluted
1:20,000 in blocking solution, was continued for $48 \mathrm{~h}$. The antiserum was a kind gift from H.-J. Agricola (University of Jena) and was previously used for crayfish (Utting et al., 2000). After washing for $2.5 \mathrm{~h}$, the biotinylated anti-rabbit secondary antibody (ABC kit, Vector Laboratories, Burlingame, CA, USA) was applied at a dilution of 1:1,000 in blocking solution overnight. After three washing cycles in washing buffer without sodium azide, $2 \mathrm{~h}$ each, the horseradish peroxidasecontaining ABC-complex (each compound diluted 1:500 in washing buffer) was allowed to bind for $12 \mathrm{~h}$. Colour development was obtained with $0.001 \%$ diaminobenzidine and $0.002 \%$ ammonium nickel sulphate (Fluka, Buchs, Switzerland) in $10 \mathrm{mmoll}^{-1}$ Sorensen's phosphate buffer $(\mathrm{pH}$ 7.6) and in the presence of $0.0001 \% \mathrm{H}_{2} \mathrm{O}_{2}$. Omitting the antiproctolin serum and preincubating the primary serum with $10 \mu \mathrm{mol}^{-1}$ proctolin resulted in no staining. Backfills of motoneurones with Lucifer Yellow and immunofluorescent labelling were performed as described previously (Kreissl et al., 1999). Conventional micrographs were taken using epifluorescence with the appropriate filter combinations. To merge images of double-stained tissue, the micrographs were digitised and modified only to enhance contrast using Adobe Photoshop.

\section{Contraction measurements}

Isometric contraction measurements were performed at $18^{\circ} \mathrm{C}$ with the short extensor fibres 1 and 2 of pereion segment 7 as described previously (Erxleben et al., 1995; Kreissl et al., 1999). Contractions were evoked by application of $10 \mathrm{mmol}^{-1}$ caffeine (Sigma, Deisenhofen, Germany) in saline. After each caffeine contracture, the fibres were kept for $20 \mathrm{~min}$ in saline to allow $\mathrm{Ca}^{2+}$ reloading into the SR. Before each proctolin application, at least three control measurements were taken. Only preparations with an equal peak amplitude of caffeine contractures were used. When caffeine contractures in the presence of proctolin were performed, the muscles were incubated in proctolin $\left(1 \mu \mathrm{moll}^{-1}\right)$ for $25 \mathrm{~min}$ before the addition of caffeine.

\section{Preparation of dorsal extensor fibres for biochemistry}

For biochemical investigations the animals were chilled and the sternites of the pereion, with attached flexor muscles, and the ventral nerve cord were cut away. The gut, the tubes of the digestive gland, the gonads with the vasa deferentia and the heart were removed. After exposure of the extensor muscle fibres, saline was replaced for $15 \mathrm{~min}$ with fresh saline at $18^{\circ} \mathrm{C}$, which contained either $1 \mu \mathrm{moll}^{-1}$ proctolin in tests or no proctolin in controls. Subsequently, the preparation was cooled on ice and the long fibres 5 (for nomenclature and anatomy, see Kreissl et al., 1999) were dissected and immediately frozen and stored in liquid nitrogen.

\section{SDS electrophoresis}

Fibres of the controls and tests were pooled in separate groups. The fibres were homogenised for $20 \mathrm{~min}$ in ice-cold extraction buffer (in mmoll $^{-1}$ : $100 \mathrm{Na}_{4} \mathrm{P}_{2} \mathrm{O}_{7}, 2.5$ EDTA, 15 
$\mathrm{MgCl}_{2}, 1$ Pefabloc, 5 DTT; modified according to Martinez et al., 1990). Ten fibres homogenised in $140 \mu \mathrm{l}$ extraction buffer, yielded a protein concentration of $3-4 \mathrm{mg} \mathrm{ml}^{-1}$. After homogenisation, the homogenate was centrifuged for $4 \mathrm{~min}$ at $1200 \mathrm{~g}$ to remove insoluble material. The supernatant was analysed for protein content (Bradford, 1976). The protein concentration of different samples on each gel was kept identical in order to enable comparisons between the samples. The supernatant of the homogenate was mixed with extraction buffer to obtain the desired protein concentration. Sample buffer (60 $\mathrm{mmol}^{-1}$ Tris, $10 \%$ glycerol, $5 \%$ SDS, $400 \mathrm{mmol}^{-1}$ 2-mercaptoethanesulfonic acid (MESNA), $0.04 \%$ Bromophenol Blue; $\mathrm{pH}$ 6.8) was added in a ratio of $1: 1$. In addition, $100 \mathrm{mmol}^{-1}$ Pefabloc and $490 \mathrm{mmoll}^{-1}$ DTT were added in a ratio of 1:100. To solubilize proteins, samples were heated to $100^{\circ} \mathrm{C}$ for $10 \mathrm{~min}$. Prior to electrophoresis, the samples were centrifuged for $3 \mathrm{~min}$ at $1200 \mathrm{~g}$.

SDS-gel electrophoresis was performed using $15 \%$ polyacrylamide gels. For each sample, about $30 \mu \mathrm{g}$ of protein were electrophoretically separated. Electrophoresis was run in a Mini-Protean II chamber (Bio-Rad, München, Germany) at $180 \mathrm{~V}$ and at room temperature. Gels were silver stained (Heukeshoven and Dernick, 1988).

\section{Preparation of actomyosin, myosin and thin filaments}

The preparation of actomyosin is a variant of the technique of Offer et al. (Offer et al., 1973). 25 identified muscle fibres (fibre 5) were transferred after dissection into $400 \mu \mathrm{l}$ slightly modified Guba-Straub solution (in $\mathrm{mmoll}^{-1}$ : $300 \mathrm{NaCl}, 100$ $\mathrm{NaH}_{2} \mathrm{PO}_{4}, 50 \mathrm{Na}_{2} \mathrm{HPO}_{4}, 1 \mathrm{MgCl}_{2}, 10 \mathrm{Na}_{4} \mathrm{P}_{2} \mathrm{O}_{7}, 10$ EDTA, 15 $\mathrm{NaN}_{3}, 100$ MESNA); $12 \mu \mathrm{l}$ Pefabloc $\left(100 \mathrm{mmol}^{-1}\right)$ was added and the fibres were homogenised for $15 \mathrm{~min}$ on ice. The extraction was continued by vigorous stirring for $90 \mathrm{~min}$ at $4{ }^{\circ} \mathrm{C}$. The muscle homogenate was then centrifuged at $15000 \mathrm{~g}$ for $10 \mathrm{~min}$. The supernatant fluid was removed and $4 \mathrm{ml}$ of $1 \mathrm{mmoll}^{-1}$ EDTA, $100 \mathrm{mmol}^{-1}$ MESNA were added to the supernatant. The proteins were allowed to precipitate at $4{ }^{\circ} \mathrm{C}$ for $1 \mathrm{~h}$. Following precipitation, the homogenate was centrifuged again for $10 \mathrm{~min}$ at $15000 \mathrm{~g}$, the pellet was dissolved in $500 \mu \mathrm{l} 100 \mathrm{mmoll}^{-1} \mathrm{Na}_{4} \mathrm{P}_{2} \mathrm{O}_{7}, 4 \mathrm{mmoll}^{-1}$ EDTA, $3 \mathrm{mmoll}^{-1}$ DTT, $12 \mathrm{mmoll}^{-1}$ ATP and gently stirred for $1 \mathrm{~h}$ at $4{ }^{\circ} \mathrm{C}$. Following centrifugation for $2 \mathrm{~h}$ at $105000 \mathrm{~g}$, the supernatant, which contained actomyosin, was prepared for SDS gel electrophoresis as described above.

Myosin and myosin light chains were isolated according to the method of Kendrick-Jones et al., for invertebrate muscle fibres, with slight modifications (Kendrick-Jones et al., 1976). 50 fibres (fibre 5) were homogenised in $100 \mu \mathrm{l} 6 \mathrm{moll}^{-1}$ guanidine- $\mathrm{HCl}, \quad 5 \mathrm{mmoll}^{-1}$ DTT, $2 \mathrm{mmoll}^{-1}$ EDTA, $10 \mathrm{mmoll}^{-1}$ (pH 8.0) for $10 \mathrm{~min}$. The extract was then stirred overnight at $4{ }^{\circ} \mathrm{C}$. The extract was mixed with $100 \mu$ l cold distilled water and $800 \mu \mathrm{l}$ cold ethanol was added slowly to precipitate the myosin heavy chains. After stirring for $30 \mathrm{~min}$ at $4{ }^{\circ} \mathrm{C}$, the homogenate was centrifuged for $30 \mathrm{~min}$ at $3200 \mathrm{~g}$ and $4{ }^{\circ} \mathrm{C}$. The pellet contained the myosin (mostly myosin heavy chains and less myosin light chains) and was dissolved in cold extraction buffer (in mmoll ${ }^{-1}$ : $100 \mathrm{Na}_{4} \mathrm{P}_{2} \mathrm{O}_{7}, 2.5$ EDTA, $15 \mathrm{MgCl}_{2}$, 1 Pefabloc, 5 DTT; modified according to the protocol of Martinez et al., 1990). To obtain the myosin light chains, the ethanol was removed from the supernatant with a rotary evaporator at room temperature, and guanidine$\mathrm{HCl}$ was removed by dialysis against $25 \mathrm{mmoll}^{-1}$ Tris- $\mathrm{HCl}$, pH 8.0, 0.5 $\mathrm{mmol}^{-1}$ DTT.

Proteins of the thin filament were prepared following the procedure for crayfish abdominal muscle (Watanabe et al., 1982). The fibres were homogenised in $50 \mathrm{mmoll}^{-1} \mathrm{KCl}$, $1 \mathrm{mmoll}^{-1} \mathrm{MgCl}_{2}, 6.7 \mathrm{mmoll}^{-1}$ sodium phosphate buffer, $100 \mu_{\mathrm{mol} \mathrm{l}}^{-1}$ EDTA, $5 \mathrm{mmol}^{-1}$ ATP (pH 6.0). The extract was centrifuged at $85000 \mathrm{~g}$ for $20 \mathrm{~min}$ and the supernatant was further centrifuged at $105000 \mathrm{~g}$ for $2 \mathrm{~h}$. The pellet was suspended in $50 \mathrm{mmol}^{-1} \mathrm{KCl}, 1 \mathrm{mmoll}^{-1} \mathrm{MgCl}_{2}, 100 \mu \mathrm{moll}^{-1}$ $\mathrm{CaCl}_{2}, 500 \mu \mathrm{moll}^{-1}$ DTT, $10 \mathrm{mmoll}^{-1}$ Tris (pH 6.8).

\section{Immunoblotting}

After electrophoresis, proteins were transferred to nitrocellulose membranes (NC membranes) using a Trans-Blot SD Semi-Dry Transfer Cell (1 h at room temperature, $0.8 \mathrm{~mA} \mathrm{~cm}^{-2}$; Bio-Rad, München, Germany). The NC membrane was equilibrated for $5 \mathrm{~min}$ in Tris-saline-Tween (TST: $100 \mathrm{mmol}^{-1}$ Tris, pH 7.6, $0.9 \% \mathrm{NaCl}, 0.01 \%$ Tween 20) and then kept in blocking buffer for $2 \mathrm{~h}$.

For blots probed with the anti-phosphoserine antibody, a blocking buffer with $0.5 \%$ bovine serum albumin (BSA), $1 \%$ polyvinyl-pyrrolidone (PVP), $1 \%$ polyethylene glycol (PEG 3500 ), $0.2 \%$ Tween $20,10 \mathrm{mmoll}^{-1} \mathrm{NaF}$ in phosphatebuffered saline (PBS: $1.9 \mathrm{mmoll}^{-1} \mathrm{NaH}_{2} \mathrm{PO}_{4}, 8.1 \mathrm{mmoll}^{-1}$ $\mathrm{Na}_{2} \mathrm{HPO}_{4}, 154 \mathrm{mmoll}^{-1} \mathrm{NaCl}, \mathrm{pH}$ 7.4) was used. After removal of the blocking buffer, the $\mathrm{NC}$ membrane was incubated overnight at room temperature in blocking buffer containing $1 \mu \mathrm{g} \mathrm{ml}^{-1}$ anti-phosphoserine monoclonal antibody (clone 4A3; Biomol, Hamburg, Germany). The NC membrane was then washed for $1 \mathrm{~h}$ with TST and incubated for $90 \mathrm{~min}$ at room temperature in biotinylated anti-mouse immunoglobulin $\mathrm{M}$ diluted in blocking buffer (1:500). The NC membrane was washed again for $1 \mathrm{~h}$ with TST and treated with an avidin-biotin-horseradish peroxidase complex (ABC kit, Vector Laboratories, Burlingame, CA, USA) diluted in TST (1:500). Subsequently, the NC membrane was washed with Tris-saline for $1 \mathrm{~h}$, incubated with a developing solution (ECL, Pierce, Rockford, IL, USA) for $5 \mathrm{~min}$ and placed against autoradiographic film for exposure. The densitometric evaluation of the phosphorylated bands was carried out according to the BIOMETRA evaluation-technique allowing the determination of the extinction of a fixed area. This area was constant for all the evaluated proteins. Deviations were calculated as standard deviations (S.D.). Statistical evaluation was carried out using a Student's $t$-test, assuming statistical significance when $P<0.05$.

For blots probed with the anti-troponin $\mathrm{I}_{3}$ antiserum (Sohn et al., 2000) a blocking buffer with $5 \%$ nonfat milkpowder in TST was used. After blocking, blots were incubated for $1 \mathrm{~h}$ with the anti-troponin $\mathrm{I}_{3}$ antibody, diluted 1:5000 in TST. The 

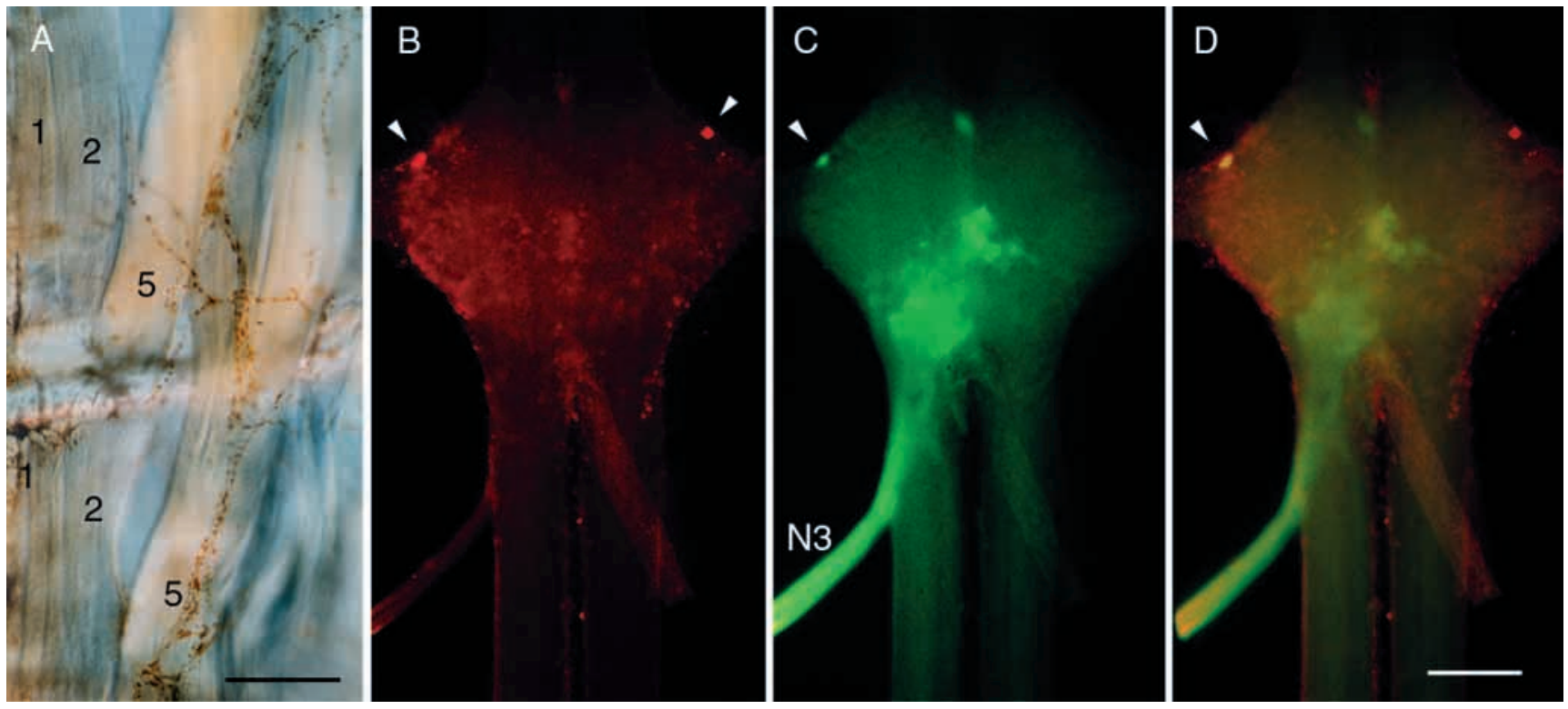

Fig. 1. Proctolin immunoreactivity on extensor muscles and in pereion ganglion 4 of I. emarginata. (A) Immunostained varicose axons extend along the inner layer of long fibres in pereion segment 7 and pleon segment 1. Numbers indicate identified muscle fibres. Anterior is up in all parts of the figure. Scale bar, $200 \mu \mathrm{m}$. (B) Proctolin immunostaining reveals a symmetric pair of neurones (arrowheads) in the anterior part of the ganglion in pereion segment 4. (C) Somata of efferent neurones projecting through N3 in the same ganglion, stained by retrograde labelling with Lucifer Yellow (arrowhead indicates the anterior motoneurone). (D) Double exposure of the specimen reveals the double labelled proctolin-ir motoneurone (arrowhead). Scale bar, $100 \mu \mathrm{m}$.

binding of the troponin $\mathrm{I}_{3}$ antibody was detected as above, using a biotinylated anti-rabbit secondary antibody (Vector Laboratories, Burlingame, CA, USA) and ECL.

\section{Results \\ Proctolin-immunoreactive innervation of dorsal extensor muscles}

The bilaterally symmetric dorsal extensor muscles in each segment of I. emarginata consist typically of a superficial dorsal layer of three to four short fibres spanning one segment, and an internal layer of two to four fibres (depending on the segment) spanning two segments (for details, see Kreissl et al., 1999). A single proctolin-immunoreactive (proctolin-ir) axon accompanies the internal layer of long muscle fibres of all pereional segments. This axon runs within the dorsal longitudinal nerve which contains the axons of other segmental motoneurones and of intersegmental modulatory neurones. The proctolin-ir axon forms numerous ovoid varicosities but only very few arborisations with bouton-like endings directly on the muscle fibres. In the pereion segment 7 and in the pleon segments 1 and 2, a plexus of varicose immunoreactive axons is present on all extensor muscle fibres (Fig. 1A). This meshwork is not in direct contact with the muscle fibres and may be a neurohaemal release site for proctolin.

The extensor muscle fibres are innervated by motoneurones located in the segmental ganglia. Their axons project through the posterior segmental nerves $3(\mathrm{~N} 3)$. In all seven specimens examined, a symmetric anterior lateral pair of proctolin-ir somata was detected only in pereion segment 4 (Fig. 1B).
Backfilling extensor motoneurones in pereion segment 4 with Lucifer Yellow through N3 visualised several groups of motoneurones and a single ipsilateral neurone in the anterior lateral part of the ganglion (Fig. 1C). Double exposure of ganglia containing backfilled somata, which were subsequently stained using indirect rhodamine immunofluorescence, revealed that this anterior lateral motoneurone contains proctolin (Fig. 1D). Thus the proctolin-ir innervation of the extensor muscles in all segments is provided by a single pair of central neurones in pereion ganglion 4 .

\section{Proctolin potentiates caffeine-induced contractures}

When isolated short extensor muscle fibres of I. emarginata were exposed to $10 \mathrm{mmoll}^{-1}$ caffeine, a contracture of the fibres resembling that described for other crustacean muscles was observed (Huddart, 1969; Chiarandini et al., 1970). The contracture persisted as long as caffeine was present $(50 \mathrm{~s})$. During a washing period of $20 \mathrm{~min}$, tension returned to the starting values, before further caffeine exposure. Proctolin $\left(1 \mu \mathrm{moll}^{-1}\right)$ increased the rate of development and the amplitude of the caffeine-induced contracture (Fig. 2A). After washing for $35 \mathrm{~min}$ with saline, the amplitude of subsequent caffeine-induced contractures returned to the level recorded before proctolin treatment (Fig. 2A,B). Although the maximal amplitude of caffeine contractures varied between experiments, this potentiating effect was consistently observed. On average, the amplitudes of caffeine contractures were significantly increased by $27 \pm 7.6 \%$ (mean \pm S.D., $N=4, P<0.05$ Student's $t$-test) in the presence of proctolin. Application of proctolin $\left(1 \mu \mathrm{mol}^{-1}\right)$ alone had no effect on resting tension. 

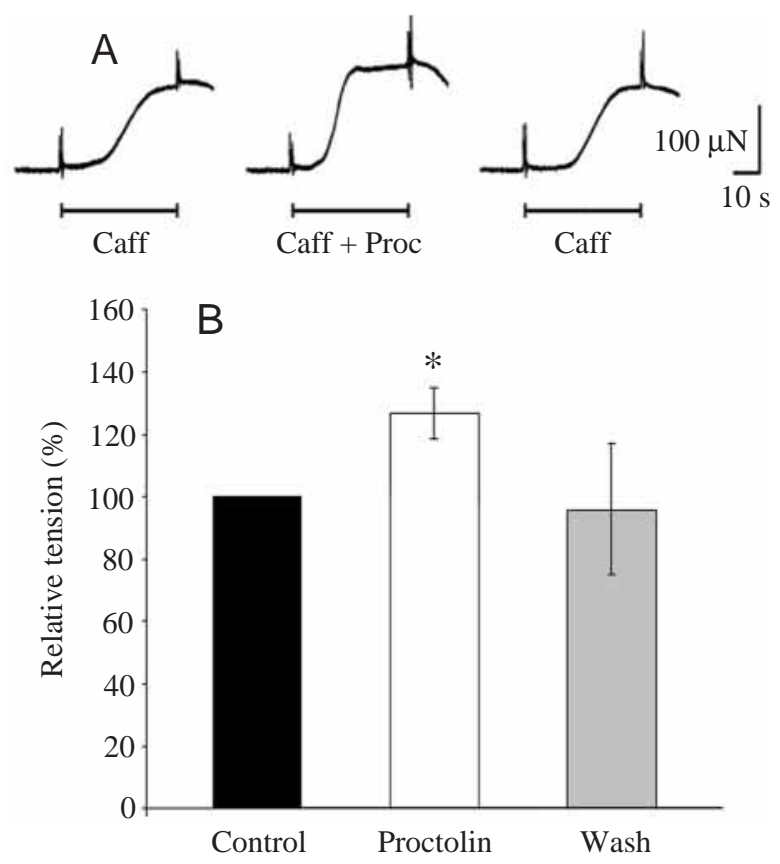

Fig. 2. Effect of proctolin on caffeine-induced contractures. (A) Potentiation of caffeine $\left(10 \mathrm{mmoll}^{-1}\right)$ contracture by $1 \mu \mathrm{mol} \mathrm{l}^{-1}$ proctolin. Two controls are shown, before and after the exposure to proctolin. (Caff, caffeine; Proc, proctolin). (B) Averages of normalised tensions obtained from 4 experiments. Control represents the average of three caffeine contractures per experiment prior to the proctolin tests. Values are means \pm S.D., $* P<0.05$, Student's $t$-test.

\section{Proctolin induces phosphorylation of a $30 \mathrm{kDa}$ protein}

The electrophoretic separation of proteins of identified long extensor muscle fibres on a $15 \%$ SDS gel yielded a number of protein bands with high resolution in the $15-100 \mathrm{kDa}$ range (Fig. 3A). To detect a change in phosphorylation of muscle proteins due to exposure to proctolin, phosphorylated proteins were identified in western blots using an anti-phosphoserine antibody. Immunoblots with a positive control (provided by Biomol, Hamburg, Germany) showed the expected labelling. In western blots of I. emarginata muscle proteins treated with the anti-phosphoserine antibody, several bands were labelled indicating that these proteins are phosphorylated at a serine residue. However, not all proteins detected by silver staining were labelled in the immunoblot (Fig. 3B). Densitometry of the immunoblot of control samples (Fig. 3C) shows different intensities of antibody staining on a number of protein bands. In western blots of proteins isolated from fibres incubated with proctolin $\left(1 \mu \mathrm{moll}^{-1}\right)$, a considerable increase in phosphorylation was evident in a protein band with the apparent molecular mass of $30 \mathrm{kDa}(N=11)$. This is evident by comparing the phosphorylation of the $30 \mathrm{kDa}$ protein in the western blots (Fig. 3B, arrow) and the two densitometric traces (Fig. 3C, arrow). The differences in phosphorylation of the 31, 35 and $36 \mathrm{kDa}$ proteins seen in Fig. 3B occurred only in this experiment and are thus not a consistent effect of proctolin.

For a quantitative analysis of the proctolin effect, the relative change of extinction was determined by comparing the extinctions of protein bands in the controls and in the proctolintreated sample of each experiment. To prove that the different intensity of staining was not due to differences in protein concentrations of the samples, the phosphorylated $70 \mathrm{kDa}$ protein was analysed as a control. The relative change of

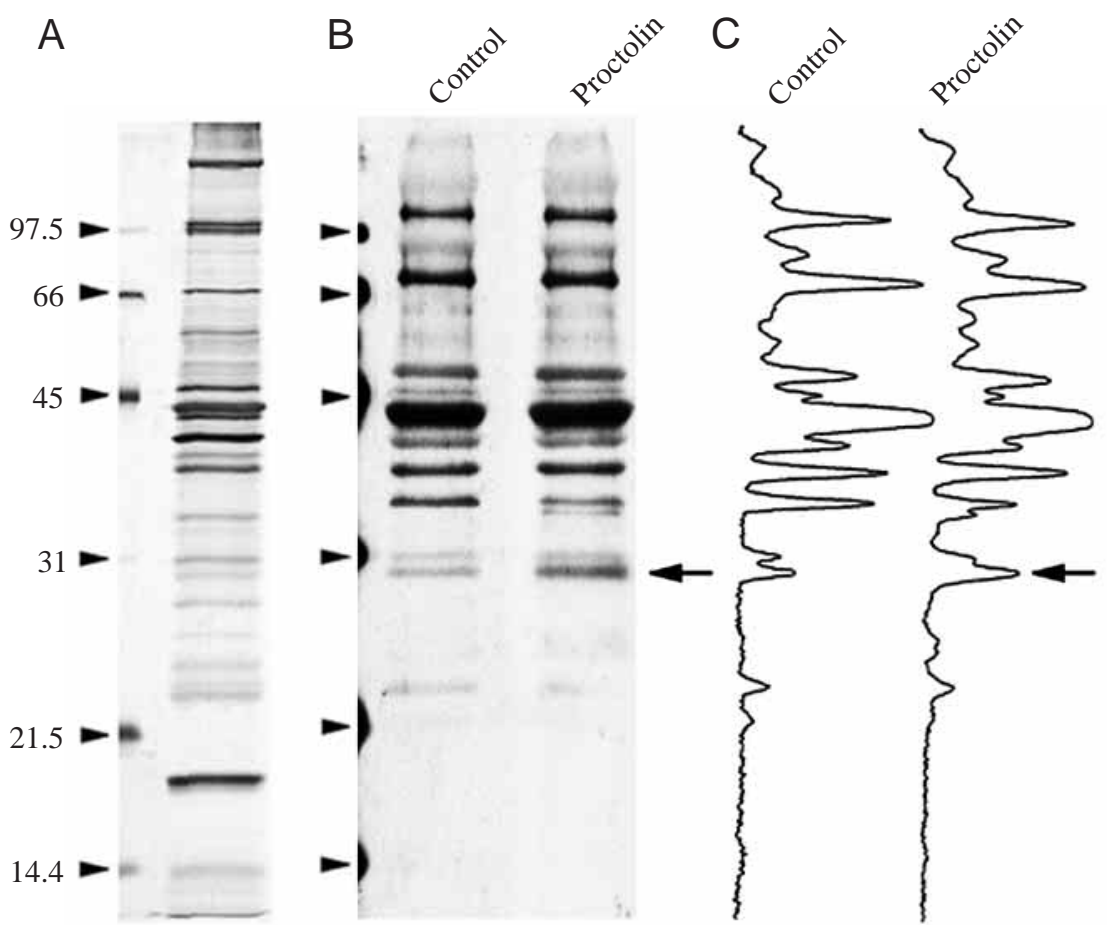

Fig. 3. (A) Electrophoretic separation of $I$. emarginata extensor muscle fibres on a $15 \%$ SDS gel. The positions of molecular mass standards $(\mathrm{kDa})$ are indicated. (B) Effect of proctolin $\left(1 \mu \mathrm{moll}^{-1}\right)$ on serine phosphorylation of $I$. emarginata extensor muscle proteins. The $30 \mathrm{kDa}$ protein band of the proctolin-treated sample (arrow) shows an increased phosphorylation signal compared to the $30 \mathrm{kDa}$ protein band of the untreated sample. Molecular mass standards are indicated by arrowheads. Although differences in phosphorylation of a $31 \mathrm{kDa}, 35 \mathrm{kDa}$ and a $36 \mathrm{kDa}$ protein are seen in this experiment, these effects do not occur consistently as an effect of proctolin incubation. (C) Densitometric analysis of B. The $30 \mathrm{kDa}$ protein band is marked (arrow). 


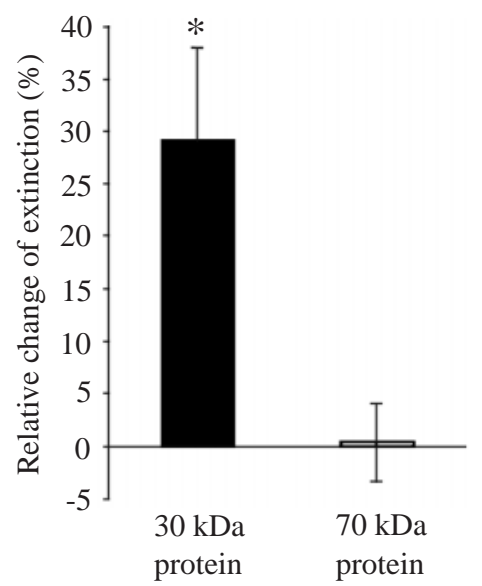

Fig. 4. Changes in relative extinction of the $30 \mathrm{kDa}$ protein and a $70 \mathrm{kDa}$ protein (for comparison) upon treatment with $1 \mu \mathrm{moll}^{-1}$ proctolin. Summary of 11 experiments. The relative changes in the extinctions of the $30 \mathrm{kDa}$ and the $70 \mathrm{kDa}$ band of proctolin-treated samples and untreated samples were compared in each experiment. The extinctions result from immunoreactivity of the antiphosphoserine antibody. Values are means \pm S.D., $* P<0.05$, Student's $t$-test. extinction of the $70 \mathrm{kDa}$ protein bands in proctolin-treated samples and in untreated samples was only small and in both directions. On average, the difference was only $0.4 \pm 3.7 \%$ (Fig. $4)$ and statistically not significant $(N=11, P>0.05$ Student's $t$ test). The proctolin effect on the phosphorylation of the $30 \mathrm{kDa}$ protein was quantitatively analysed in the same 11 experiments. In seven of these experiments, the extinction in the proctolin-treated samples was increased by $26 \%$ to $89 \%$ over the untreated samples. In two experiments, no obvious differences in the extinction of the $30 \mathrm{kDa}$ protein band was detected, and in two other experiments the extinction of the proctolin-treated samples was slightly smaller $(6 \%, 9 \%)$ than that of the untreated samples. On average, the extinction of the $30 \mathrm{kDa}$ protein band of the proctolin-treated samples was significantly increased by $29 \pm 8.9 \%(N=11, P<0.05$, Student's $t$-test). These results show that proctolin induces phosphorylation of a $30 \mathrm{kDa}$ protein in the extensor muscle fibres of I. emarginata (Fig. 4).

The phosphorylated $30 \mathrm{kDa}$ protein is associated with the thin filament and troponin I immunoreactive

Since the phosphorylated $30 \mathrm{kDa}$ protein band is present in

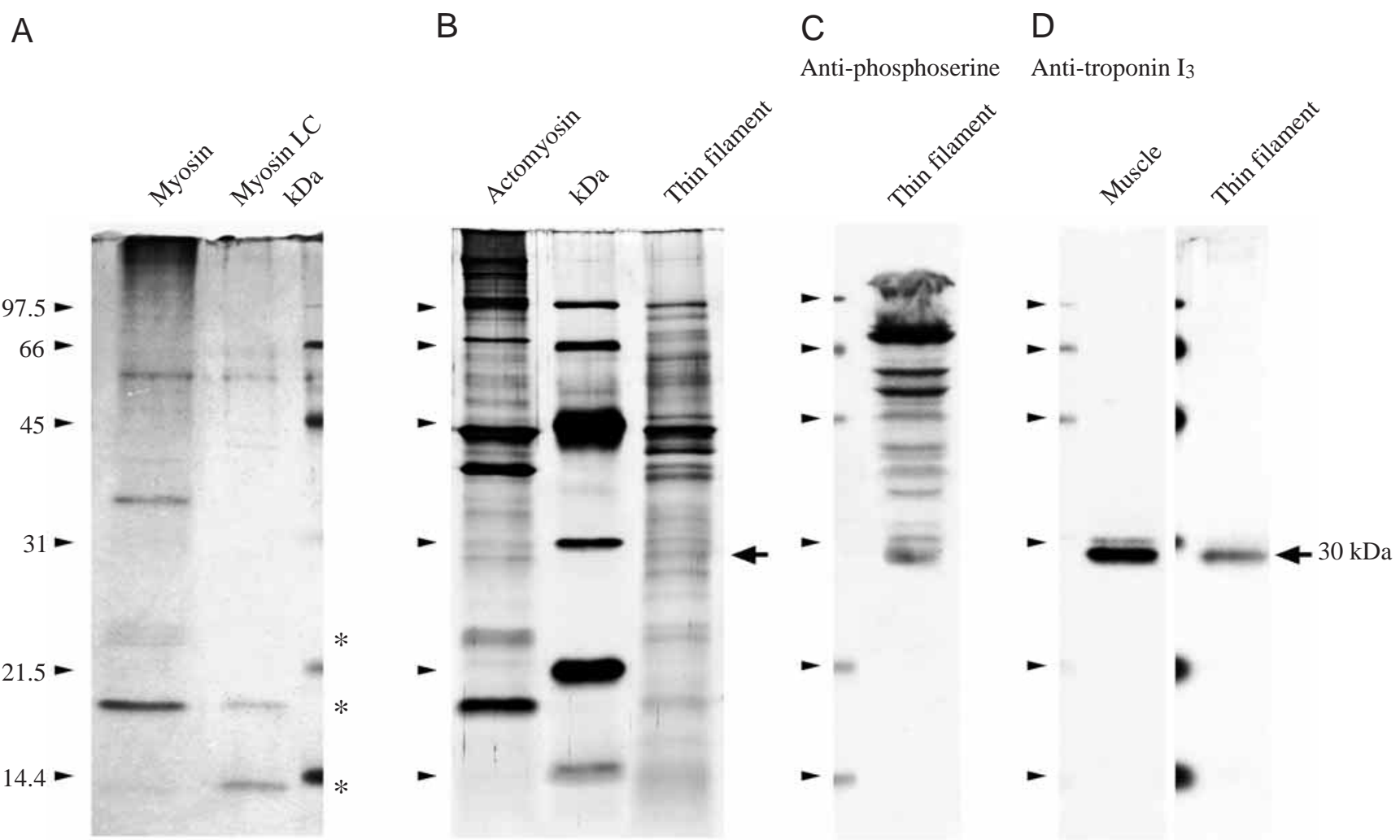

Fig. 5. Electrophoretic separation and western blot analysis of I. emarginata myosin, actomyosin and thin filament on $15 \%$ SDS gels. The positions of molecular mass standards $(\mathrm{kDa})$ are indicated. (A) In the myosin extract three myosin light chains (myosin LC) were identified (asterisks). In myosin LC extracts obtained by guanidine- $\mathrm{HCl}$ precipitation two of these light chains (14 kDa and $18.5 \mathrm{kDa})$ are present. (B) The actomyosin and thin filament extracts contain a protein with the apparent molecular mass of $30 \mathrm{kDa}$ (arrow), whereas no such protein is present in the myosin extract. (C) Western blot analysis with a phosphoserine antibody reveals a number of high molecular mass proteins and two proteins at $30 \mathrm{kDa}$ and $31 \mathrm{kDa}$ in thin filament preparations. (D) In I. emarginata muscle homogenates and thin filament preparations, a major band at $30 \mathrm{kDa}$ (arrow) and a minor band at $31 \mathrm{kDa}$ are stained in western blot analysis with antiserum against lobster troponin $\mathrm{I}_{3}$. 
preparations of sarcoplasmic proteins (Fig. 3), we assumed that it is associated with either the thin or the thick filament. To determine whether the potentiation of caffeine-induced muscle contraction is due to myosin light chain phosphorylation we identified myosin light chains of I. emarginata. Electrophoretic separation of the myosin preparation revealed three protein bands at $14,18.5$ and $24 \mathrm{kDa}$ and a prominent band at the apparent molecular mass of $189 \mathrm{kDa}$ (Fig. 5A). The molecular masses of these proteins correspond to those reported for myosin light and heavy chains of other crustacean muscles (Mykles, 1985a; Mykles, 1985b; Mykles, 1988; Li and Mykles, 1990). The protein bands at $36 \mathrm{kDa}$ and $56 \mathrm{kDa}$ do not correspond to any known crustacean myosin light chains and are therefore supposed to be contaminants. By subsequent treatment with guanidine- $\mathrm{HCl}$ and precipitation of heavy chains with ethanol, the two myosin light chains with molecular masses of $14 \mathrm{kDa}$ and $18.5 \mathrm{kDa}$ were further separated (Fig. 5A). A $30 \mathrm{kDa}$ protein that was present in the actomyosin preparation (Fig. 5B) was not present in the myosin preparation. We therefore concluded that proctolin does not induce myosin light chain phosphorylation.

The preparation and electrophoretic separation of the thin filament proteins showed a number of different bands with apparent molecular masses between 14 and $100 \mathrm{kDa}$ (Fig. 5B). Among these, two protein bands at $30 \mathrm{kDa}$ and $31 \mathrm{kDa}$ are visible (Fig. 5B, arrow at $30 \mathrm{kDa}$ ). Thus, these proteins belong to the thin filament complex, and are most probably thin-filament-associated regulatory proteins. Both are phosphorylated at a serine residue (Fig. 5C). Since in other crustacean muscles thin filament proteins with the molecular mass of approximately $30 \mathrm{kDa}$ inhibit actomyosin-ATPase activity and have therefore been classified as troponin I (Regenstein and Szent-Györgyi, 1975; Mykles, 1985a; Nishita and Ojima, 1990; Miegel et al., 1992; Neil et al., 1993), we applied an antiserum, generated against lobster troponin $\mathrm{I}_{3}$ (Sohn et al., 2000), onto I. emarginata muscle and thin filament preparations (Fig. 5D). The immunoblot revealed only two bands: one major band of $30 \mathrm{kDa}$ and another minor band of $31 \mathrm{kDa}$. There was no signal with the anti-troponin $\mathrm{I}_{3}$ antiserum on I. emarginata myosin preparations. From these results we suggest that proctolin induces phosphorylation of the $30 \mathrm{kDa}$ troponin I isoform in I. emarginata muscle.

\section{Discussion \\ Immunocytochemistry}

The potentiating effects of proctolin on Idotea extensor muscle fibres (Erxleben et al., 1995) raised the question of whether the peptide is present in I. emarginata and how it reaches the fibres in vivo. We identified a single pair of proctolin-ir motoneurones in pereion ganglion 4, which appears to be the only central source for directly supplying proctolin to the extensor muscles in all segments. The axons of these motoneurones accompany the internal layer of long extensor muscle fibres across several segments and form a neurohaemal meshwork of varicosities in the posterior body segments, allowing modulation of local and more distant targets. This mode of release has also been found in other arthropods (Anwyl and Finlayson, 1973; Bräunig, 1997). We have recently localised allatostatin immunoreactivity in pairs of motoneurones with similar location and morphology in all pereion ganglia except ganglion 4 of I. emarginata (Kreissl et al., 1999). Thus, the modulatory action of these homonomous pairs of neurones present in all pereion ganglia is exerted by different peptides which are segment-specifically expressed but applied to extensor muscle fibres in all segments.

\section{Mechanisms of proctolin-induced potentiation of contraction}

Proctolin enhances contraction by synergistic pre- and postsynaptic effects. In I. emarginata the postsynaptic effects induced by concentrations of proctolin in the range of $2 \mathrm{nmoll}^{-1}$ to $1 \mu \mathrm{moll}^{-1}$ include an increase in the input resistance of the sarcolemma by closure of non-voltagedependent $\mathrm{K}^{+}$channels and an increase of inward current through L-type $\mathrm{Ca}^{2+}$ channels (Erxleben et al., 1995; Rathmayer et al., 2001). The involvement of intracellular signalling pathways (Lange and Nykamp, 1996, for review; Rathmayer et al., 2001) suggests that, in addition to the effects on sarcolemmal ion channels, proctolin may also modulate $\mathrm{Ca}^{2+}$ release from the SR and/or $\mathrm{Ca}^{2+}$ sensitivity of sarcoplasmic proteins. In this study we show that proctolin, when applied at the concentration that was most effective in previous studies on this preparation $\left(1 \mu \mathrm{moll}^{-1}\right)$, enhances caffeine contractures of I. emarginata extensor muscle fibres and induces the phosphorylation of a $30 \mathrm{kDa}$ protein. The proctolin-induced activation of $\mathrm{Ca}^{2+}$ channels does not contribute to the proctolin-induced enhancement of caffeine contractures. Caffeine contractures, which develop without membrane depolarisations, are not accompanied by $\mathrm{Ca}^{2+}$ currents through voltage-dependent $\mathrm{Ca}^{2+}$ channels (Huddart, 1969; Chiarandini et al., 1970). Caffeine contractures are thought to be due to its effect on the ryanodine receptor engaged in $\mathrm{Ca}^{2+}$ release from the SR. Since in locust oviduct and foregut muscles proctolin causes an increase in $\operatorname{Ins} P_{3}$, and injection of Ins $P_{3}$ and phorbol esters mimicked the effect of proctolin (Baines and Downer, 1992; Lange and Nykamp, 1996; Hinton et al., 1998), it was suggested by these authors that the potentiation of contractions by proctolin is mediated by activation of Ins $P_{3}$-induced $\mathrm{Ca}^{2+}$ release from the SR. At present we have not investigated a possible potentiating effect of proctolin on caffeine contractures caused by a change in $\mathrm{Ca}^{2+}$ release.

However, proctolin may have yet another mechanism of action that is downstream of the $\mathrm{Ca}^{2+}$ release from the SR, by changing the $\mathrm{Ca}^{2+}$ sensitivity of regulatory proteins through phosphorylation.

\section{Proctolin induces phosphorylation of an intramuscular protein}

As the present study demonstrates, proctolin induces serine phosphorylation of a muscle protein with the apparent molecular mass of $30 \mathrm{kDa}$. No other protein shows a consistent 


\section{B. BRÜSTLE AND OTHERS}

change in its degree of serine phosphorylation on exposure to proctolin. However, considerable variability in the proctolininduced phosphorylation can be detected, which may reflect different endogenous proctolin levels. Erxleben et al. (Erxleben et al., 1995) reported a considerable variability among preparations of $I$. baltica for the proctolin-induced enhancement of contraction. Sometimes proctolin even failed to exert any effect on membrane properties or contraction amplitudes. The effects of proctolin was also shown to vary seasonally in crayfish (Bishop et al., 1991b).

To study phosphorylation of muscle proteins, we chose an extraction method that would isolate sarcoplasmic proteins in the range $15-200 \mathrm{kDa}$. Therefore, membrane-bound proteins such as ion channels were not present in the homogenates. In myofibrillar proteins, phosphorylation of myosin regulatory light chains, which is common in vertebrate muscle and regulates force generation (Sweeney et al., 1993; Horowitz et al., 1996, for review), has been detected in several insects (Winkelman and Bullard, 1980; Takano-Ohmuro et al., 1986). Lange and Nykamp (Lange and Nykamp, 1996) reported that a $20 \mathrm{kDa}$ light chain of a locust visceral muscle is phosphorylated after proctolin exposure $\left(10 \mathrm{nmoll}^{-1}\right)$. In Drososphila flight muscle phosphorylation of a light chain enhanced both calcium-activated and magnesium-activated ATPase activities (Takahashi et al., 1990). We show that the $30 \mathrm{kDa}$ protein of I. emarginata muscles, the phosphorylation of which is modulated by proctolin, is not a myosin light chain because the protein is not present in the myosin preparations (Fig. 5A). In the opener muscle of lobster walking legs, the biogenic amines serotonin and octopamine, but not proctolin, were found to induce phosphorylation of a $29 \mathrm{kDa}$ protein (Goy et al., 1984). Although the molecular mass of this protein is similar to that of the I. emarginata protein, the lobster protein is soluble and not associated with myofibrils and therefore not likely to correspond to the I. emarginata $30 \mathrm{kDa}$ protein.

In crustacean muscles, thin filament regulatory proteins in the $30 \mathrm{kDa}$ range have been classified as troponin I because they inhibit actomyosin-ATPase activity (Regenstein and Szent-Györgyi, 1975; Nishita and Ojima, 1990). Five different troponin I isoforms, with molecular masses between 27 and $30 \mathrm{kDa}$, were found in lobster fast and slow muscles (Mykles, 1985a; Mykles, 1985b; Miegel et al., 1992; Neil et al., 1993). By applying an anti-troponin $\mathrm{I}_{3}$ antiserum that was made against lobster troponin $\mathrm{I}_{3}$ but which reacts with other troponin I isoforms, we provide evidence that I. emarginata muscle contains at least two troponin I isoforms. Both are phosphorylated but proctolin increases the phosphorylation of only the $30 \mathrm{kDa}$ protein.

A functional role of troponin I phosphorylation is well known from studies of vertebrate heart muscle (for review see Perry, 1999). In parallel with the $\beta$-adrenergic-positive inotropic effect, the phosphorylation of troponin I leads to an reduction of the $\mathrm{Ca}^{2+}$ sensitivity of troponin $\mathrm{C}$ (Reiffert et al., 1996; Jaquet et al., 1998). It is not known if phosphorylation of troponin I in crustacean muscle takes place in vivo. If the analogy with vertebrate heart muscle is valid this effect of proctolin in I. emarginata muscle fibres would counteract the other effects of this peptide in this preparation.

However, possible serine phosphorylation sites of troponin I from the crayfish Astacus leptodactylus are not thought to contribute to a control mechanism equivalent to the negative feedback mechanism in vertebrate heart muscle (Kobayashi et al., 1989). In addition, recent studies in an insect muscle showed that phosphorylation of a thin filament-associated $30 \mathrm{kDa}$ protein actually increased $\mathrm{Ca}^{2+}$ sensitivity of the actomyosin ATPase (Weitkamp et al., 1998). The identity of this $30 \mathrm{kDa}$ protein is not known but the authors assume it to be a troponin I on the basis of its molecular mass.

If the phosphorylation of the I. emarginata $30 \mathrm{kDa}$ thinfilament-associated protein also increases $\mathrm{Ca}^{2+}$ sensitivity of the ATPase, this would contribute to the proctolin-induced potentiation of contractures and would be synergistic to all other effects of proctolin in this preparation.

This work was supported by grants of the Deutsche Forschungsgemeinschaft ( $\mathrm{Ra}$ 113/9-1). We thank Dr H.-J. Agricola for the proctolin antiserum, M. A. Cahill and B. Rapp for valuable technical assistance, and M. Thimm for rearing the animals.

\section{References}

Anwyl, R. and Finlayson, L. H. (1973). The ultrastructure of neurons with both a motor and a neurosecretory function in the insect Rhodnius prolixus. Z. Zellforsch. 146, 367-374.

Baines, R. A. and Downer, R. G. H. (1992). Comparative studies on the mode of action of proctolin and phorbol-12,13-dibutyrate in their ability to contract the locust mandibular closer muscle. Arch. Insect Biochem. Physiol. 20, 215-229.

Baines, R. A., Walther, C., Hinton, J. M., Osborne, R. H. and Konopinska, D. (1996). Selective activity of a proctolin analogue reveals the existence of two receptor subtypes. J. Neurophysiol. 75, 2647-2650.

Bárány, M. and Bárány, K. (1980). Phosphorylation of the myofibrillar proteins. Annu. Rev. Physiol. 42, 275-292.

Belanger, J. H. and Orchard, I. (1993). The locust ovipositor opener muscle: Proctolinergic central and peripheral neuromodulation in a centrally driven motor system. J. Exp. Biol. 174, 343-362.

Bishop, C. A., Krouse, M. E. and Wine, J. J. (1991a). Peptide cotransmitter potentiates calcium channel activity in crayfish skeletal muscle. J. Neurosci. 11, 269-276.

Bishop, C. A., Krouse, M. E. and Wine, J. J. (1991b). Peptide potentiation of calcium channel activity can be seasonally variable. J. Exp. Biol. 156, 607-610.

Bradford, M. (1976). A rapid and sensitive method for the quantitation of microgram quantities of protein utilizing the principle of protein-dye binding. Anal. Biochem. 72, 248-254.

Bräunig, P. (1997). The peripheral branching pattern of identified dorsal unpaired median (DUM) neurones in the locust. Cell Tissue Res. 290, 641-654.

Brown, B. E. and Starrat, A. N. (1975). Isolation of proctolin, a myotropic peptide, from Periplaneta americana. J. Insect Physiol. 21,1879-1881.

Chiarandini, D. J., Reuben, J. P., Brandt, P. W. and Grundfest, H. (1970). Effects of caffeine on crayfish muscle fibers. I. Activation of contraction and induction of Ca spike electrogenesis. J. Gen. Physiol. 55, 640-687.

Erxleben, C. F. J. and deSantis, A. (1998). Properties of the calcium current in crustacean muscle and modulation by proctolin through activation of second messenger pathways. In Proceedings of the 26th Göttingen Neurobiology Conference, vol. II (ed. N. Elsner and R. Wehner), p. 605. Stuttgart: Thieme.

Erxleben, C. F. J., deSantis, A. and Rathmayer, W. (1995). Effects of proctolin on contractions, membrane resistance, and non-voltage-dependent 
sarcolemmal ion channels in crustacean muscle fibers. J. Neurosci. 15, 4356-4369.

Evans, P. D. (1984). Studies on the mode of action of octopamine, 5hydroxytryptamine and proctolin on the myogenic rhythm in the locust. $J$. Exp. Biol. 110, 231-251.

Evans, P. D. and Myers, C. M. (1986). Peptidergic and aminergic modulation of insect skeletal muscle. J. Exp. Biol. 124, 143-176.

Facciponte, G., Miksys, S. and Lange, A. B. (1996). The association of proctolin with a ventral abdominal muscle of Locusta migratoria. J. Comp. Physiol. A 178, 269-278.

Goy, M. F., Schwarz, T. L. and Kravitz, E. A. (1984). Serotonin-induced protein phosphorylation in a lobster neuromuscular preparation. J. Neurosci. 4, 611-626.

Heukeshoven, J. and Dernick, R. (1988). Improved silver staining procedure for fast staining in PhastSystem Development Unit. I. Staining of sodium dodecyl sulfate gels. Electrophoresis 9, 28-32.

Hinton, J. M., Nejad, M., Issberner, J. P., Hancock, J. T. and Osborne, R. H. (1998). Muscarinic acetylcholine and proctolin receptors in the foregut of the locust Schistocerca gregaria: role of inositol phosphates, protein kinase $\mathrm{C}$ and calcium in second messenger effects. Insect Biochem. Mol. Biol. 28, 331-343.

Horowitz, A., Menice, C. B., Laporte, R. and Morgan, K. G. (1996). Mechanisms of smooth muscle contraction. Physiol. Rev. 76, 967-1003.

Huddart, H. (1969). Caffeine activation of crab skeletal muscle. Comp. Biochem. Physiol. 29, 1031-1038.

Jaquet, K., Lohmann, K., Czisch, M., Holak, T., Gulati, J. and Jaquet, R. (1998). A model for the function of the bisphosphorylated heart-specific troponin-I N-terminus. J. Musc. Res. Cell Motil. 19, 647-659.

Jorge-Rivera, J. C., Sen, K., Birmingham, J. T., Abbott, L. F. and Marder, E. (1998). Temporal dynamics of convergent modulation at a crustacean neuromuscular junction. J. Neurophysiol. 80, 2559-2570.

Kendrick-Jones, J., Szentkiralyi, E. M. and Szent-Györgyi, A. G. (1976). Regularory light chains in myosins. J. Mol. Biol. 104, 747-775.

Kobayashi, T., Takagi, T., Konishi, S. and Cox, J. A. (1989). Amino acid sequence of crayfish troponin I. J. Biol. Chem. 264, 1551-1557.

Kreissl, S., Weiss, T., Djokaj, S., Balezina, O. and Rathmayer, W. (1999). Allatostatin modulates skeletal muscle performance in crustaceans through pre- and postsynaptic effects. Eur. J. Neurosci. 11, 2519-2530.

Lange, A. B., Orchard, I. and Adams, M. E. (1986). Peptidergic innervation of insect reproductive tissue - the association of proctolin with oviduct visceral musculature. J. Comp. Neurol. 254, 279-286.

Lange, A. B. and Nykamp, D. A. (1996). Signal transduction pathways regulating the contraction of an insect visceral muscle. Arch. Insect Biochem. Physiol. 33, 183-196.

Lea, T. J. (1996). Caffeine and micromolar $\mathrm{Ca}^{2+}$ concentrations can release $\mathrm{Ca}^{2+}$ from ryanodine-sensitive stores in crab and lobster striated muscle fibres. J. Exp. Biol. 199, 2419-2428.

Li, Y. and Mykles, D. L. (1990). Analysis of myosins from lobster muscles: fast and slow isozymes differ in heavy-chain composition. J. Exp. Zool. 255 , $163-170$.

Martinez, I., Ofstad, R. and Olsen, R. (1990). Electrophoretic study of myosin isoforms in white muscles of some teleost fishes. Comp. Biochem. Physiol. 96B, 221-227.

Mazzocco-Manneval, C., Kuczer, M., Konopinska, D., Fournier, B., Loughton, B. G. and Puiroux, J. (1998). Pharmacological studies of proctolin receptors on foregut and hindgut of Blaberus craniifer. Peptides 19, 1641-1651.

Miegel, A., Kobayashi, T. and Maéda, Y. (1992). Isolation, purification and partial characterization of tropomyosin and troponin subunits from the lobster tail muscle. J. Musc. Res. Cell Motil. 13, 608-618.

Mykles, D. L. (1985a). Heterogenity of myofibrillar proteins in lobster fast and slow muscles: variants of troponin, paramyosin, and myosin light chains comprise four distinct protein assemblages. J. Exp. Zool. 234, 23-32.

Mykles, D. L. (1985b). Multiple variants of myofibrillar proteins in single fibers of lobster claw muscles: evidence for two types of slow fibers in the cutter closer muscle. Biol. Bull. 169, 476-483.

Mykles, D. L. (1988). Histochemical and biochemical characterization of two slow fiber types in decapod crustacean muscles. J. Exp. Zool. 245, 232-243.

Neil, D. M., Fowler, W. S., and Tobasnick, G. (1993). Myofibrillar protein composition correlates with histochemistry in fibres of the abdominal flexor muscles of the norway lobster Nephros norvegicus. J. Exp. Biol. 183, 185-201.

Nishita, K. and Ojima, T. (1990). American lobster troponin. J. Biochem. (Tokyo) 108, 677-683

O'Shea, M. (1985). Are skeletal motoneurons in arthropods peptidergic? In Model Neural Networks and Behaviour (ed. A. I. Selverston), pp. 401-413. New York: Plenum Press.

Offer, G., Moos, C. and Starr, R. (1973). A new protein of the thick filaments of vertebrate skeletal myofibrils. Extraction, purification and characterization. J. Mol. Biol. 74, 653-676.

Orchard, I., Belanger, J. H. and Lange, A. B. (1989). Proctolin: A review with emphasis on insects. J. Neurobiol. 20, 470-496.

Pasztor, V. M. and Golas, L. B. (1993). The modulatory effects of serotonin, neuropeptide F1 and proctolin on the receptor muscles of the lobster abdominal stretch receptor and their exoskeletal muscle homologues. J. Exp. Biol. 174, 363-374.

Perry, S. V. (1999). Troponin I: inhibitor or facilitator. Mol. Cell. Biochem. 190, 9-32.

Rathmayer, W., Erxleben, C., Djokaj, S., Gaydukov, A., Kreissl, S. and Weiss, T. (2001). Antagonistic modulation of neuromuscular parameters in crustaceans by the peptides proctolin and allatostatin, contained in identified motor neurons. In Frontiers in Crustacean Neuroscience (ed. K. Wiese). Berlin: Springer (in press).

Regenstein, J. M. and Szent-Györgyi, A. G. (1975). Regulatory proteins of lobster striated muscle. Biochemistry 14, 917-925.

Reiffert, S. U., Jaquet, K., Heilmeyer, L. M. Jr., Ritchie, M. D. and Geeves, M. A. (1996). Bisphosphorylation of cardiac troponin I modulates the $\mathrm{Ca}^{2+}$ dependent binding of myosin subfragment $\mathrm{S} 1$ to reconstituted thin filaments. FEBS Lett. 384, 43-47.

Schwarz, T. L., Harris-Warrick, R. M., Glusman, S. and Kravitz, E. A. (1980). A peptide action in a lobster neuromuscular preparation. $J$. Neurobiol. 11, 623-628.

Siwicki, K. K., Beltz, B. S. and Kravitz, E. A. (1987). Proctolin in identified serotonergic, dopaminergic and cholinergic neurons in the lobster Homarus americanus. J. Neurosci. 7, 522-532.

Sohn, J., Mykles, D. L. and Cooper, R. L. (2000). Characterization of muscles associated with the articular membrane in the dorsal surface of the crayfish abdomen. J. Exp. Zool. 287, 353-377.

Sweeney, H. L., Bowman, B. F. and Stull, J. T. (1993). Myosin light chain phosphorylation in vertebrate striated muscle: regulation and function. Am. J. Physiol. 264, C1085-C1095.

Takahashi, S., Takano-Ohmuro, H. and Maruyama, K. (1990). Regulation of Drosophila myosin ATPase activity by phosphorylation of myosin light chains. I. Wild type fly. Comp. Biochem. Physiol. 95B, 179-181.

Takano-Ohmuro, H., Tanikawa, M. and Maruyama, K. (1986). Phosphorylation of cricket myosin light chain and $\mathrm{Mg}^{2+}$-activated actomyosin ATPase activity. Zool. Sci. 3, 715-717.

Utting, M., Agricola, H.-J., Sandeman, R. and Sandeman, D. (2000). Central complex in the brain of crayfish and its possible homology with that of insects. J. Comp. Neurol. 416, 245-261.

Walther, C., Zittlau, K. E., Murck, H. and Voigt, K. (1998). Resting membrane properties of locust muscle and their modulation I. Actions of the neuropeptides YGGFMRFamide and proctolin. J. Neurophysiol. 80, $771-784$.

Watanabe, K., Kitaura, T. and Yamaguchi, M. (1982). Crayfish myosin has no $\mathrm{Ca}^{2+}$ dependent regulation in actomyosin. J. Biochem. 92, 1635-1641.

Wegener, C. and Nässel, D. R. (2000). Peptide-induced $\mathrm{Ca}^{2+}$ movements in a tonic insect muscle: Effects of proctolin and periviscerokinin-2. J. Neurophysiol. 84, 3056-3066.

Weitkamp, B., Jurk, K. and Beinbrech, G. (1998). Projectin-thin filament interactions and modulation of the sensitivity of the actomyosin ATPase to calcium by projectin kinase. J. Biol. Chem. 273, 19802-19808.

Wilcox, C. L. and Lange, A. B. (1995). Role of extracellular and intracellular calcium on proctolin-induced contractions in an insect visceral muscle. Regul. Pept. 56, 49-59.

Winkelman, L. and Bullard, B. (1980). Phosphorylation of a locust myosin light chain and its effect on calcium regulation. J. Musc. Res. Cell Motil. 1, 221-222.

Zhang, J. J., Williams, A. J. and Sitsapesan, R. (1999). Evidence for novel caffeine and $\mathrm{Ca}^{2+}$ binding sites on the lobster skeletal ryanodine receptor. Br. J. Pharmacol. 126, 1066-1074. 